\title{
PENGARUH KONFLIK TERHADAP PEMBANGUNAN PENDIDIKAN DI ACEH
}

\author{
Khairul Amin \\ Program Studi Magister Sosiologi \\ Universitas Malikussaleh Lhokseumawe, Aceh \\ Alqonz90@gmail.com
}

\begin{abstract}
This paper aims to discuss how the impact of conflict on the development of education in Aceh today, because Aceh as a conflict area have different conditions with other areas in indonesia, especially in the development of education. This paper is prepared using a literature study approach, in which data are collected from secondary sources in the form of documents related to current educational development, as well as the results of research related to conflict and educational development. Current conditions indicate that Aceh's educational participation is growing rapidly and exceeding than other areas not affected by the conflict. Conflict has contributed to the acceleration of educational development for the people of Aceh today. The success of educational development is indicated by the increasing number of educational development indicators (APS, APM, HLS, ARLS etc) that surpass the national average. When compared to other areas not exposed to conflict, the development of education in Aceh is quite successful.
\end{abstract}

Keywords: Impact, Conflict, Education, Aceh

\begin{abstract}
Abstrak
Tulisan ini bermaksud mengkaji tentang bagaimana pengaruh konflik terhadap pengembangan pendidikan di Aceh saat ini, karena Aceh sebagai daerah konflik tentu memiliki dinamika yang berbeda dengan daerah lain yang tidak berkonflik, tertutama dalam pengembangan pendidikannya. Tulisan ini disusun dengan

Nazhruna: Jurnal Pendidikan Islam
\end{abstract}

Vol. 1 No 2 Agustus 2018. Issn: 2614-8013. Hal. 159-176 
menggunakan pendekatan studi literatur, dimana data dihimpun dari sumber-sumber skunder yang berupa dokumen-dokumen terkait kinerja pembangunan pendidikan saat ini, serta hasil-hasil kajian atau penelitian terkait konflik dan pembangunan dunia pendidikan. Kondisi saat ini menunjukkan bahwa partisipasi pendidikan masyarakat Aceh bertumbuh dengan cepat dan melebihi daerah lain yang tidak terdampak konflik. Konflik yang berkepanjangan memberikan andil dalam akselerasi pembangunan pendidikan bagi masyarakat Aceh saat ini. Kesuksesan pembangunan pendidikan di Aceh terlihat jelas dari meningkatnya angka indikator pembangunan pendidikan (APS, APM, HLS, ARLS dls) yang melampaui angka rata-rata nasional. Jika dibandingkan dengan daerah lain yang tidak terpapar konflik, pembangunan pendidikan di Aceh dapat dikatakan sudah cukup berhasil.

Kata kunci: Pengaruh, Konflik, Pendidikan, Aceh

\section{Pendahuluan}

Pada tahun 1873 kerajaan Belanda memproklamirkan perang kepada Aceh dan sejak saat itu hingga awal abad ke 20, Aceh tidak pernah berhenti bergejolak. Beragam konflik dan peperangan terus mengiringi perjalanan sejarah rakyat Aceh hingga saat ini. Ribuan hingga jutaan nyawa telah menjadi korban keganasan konflik dan peperangan yang terjadi di Aceh, ratusan hingga ribuan perempuan terpaksa menjanda, anak-anak pun harus kehilangan pendidikan dan orang tuanya. Pasca Kemerdekaan Republik Indonesia, mulai 2 Desember 1945 hingga 16 Januari 1946 Aceh terjebak dalam perang saudara yaitu perang cumbok atau lebih dikenal dengan istilah revolusi sosial yang mengorbankan 1500 rakyatnya. Pada kurun waktu 19531964 sekitar 4000 orang menjadi korban dalam peristiwa pemberontakan Darul Islam yang dipimpin oleh Daud Beurueh atau lebih dikenal dengan pemberontakan DI/TII. Lalu pada tahun 1976 Gerakan Aceh Merdeka (GAM) mendeklarasikan diri, pada tahun 1998 terjadi konflik bersenjata antara GAM dan Militer, 3500 orang menjadi 
korban dan meninggalkan luka yang mendalam bagi rakyat Aceh (KOMNAS HAM). Tidak hanya berhenti sampai disitu, Aceh kembali dilanda musibah tsunami pada 26 Desember 2004. Menurut data Departemen Sosial, korban gempa dan tsunami di Aceh mencapai angka 105.262 orang, total luka-luka sebanyak 124.057 orang, hilang 14.000 orang, dan kehilangan tempat tinggal 1.126.900 orang ${ }^{1}$

Berbagai macam cara telah dilakukan untuk menghentikan konflik di Aceh. Pada masa orde baru, penyelesaian konflik Aceh lebih mengedepankan pendekatan keamanan (security approuch) dari pada pendekatan dialog${ }^{2}$. Operasi berkepanjangan yang dilancarkan oleh pemerintah Orde Baru kala itu telah menimbulkan berbagai bentuk pelanggaran hak asasi manusia, mulai dari pembunuhan misterius, extrajudicial killing, penghilangan orang secara paksa, penangkapan dan penahanan sewenang-wenang, penyiksaan, serta berbagai bentuk penghukuman kejam yang merendahkan martabat manusia. Aceh sebagai daerah operasi militer baru berakhir bersamaan dengan runtuhnya Orde Baru pada 1998, tepatnya pada tanggal 7 Agustus 1998, Presiden Habibie secara resmi mencabut pelaksanan operasi militer (DOM) di Aceh. Namun berakhirnya DOM tidak membuat gejolak yang terjadi di Aceh mereda, bahkan aksi-aksi kekerasan terhadap rakyak Aceh masih sering terjadi. Sejumlah peristiwa kekerasan dan pembantaian sepanjang 1999 hingga tahun 2001 masih terjadi. Setidaknya ada tujuh peristiwa terkenal yang terjadi dalam kurun waktu tersebut, diantaranya peristiwa Simpang KKA dimana aparat TNI menembaki masyarakat yang sedang berdemonstrasi di Kecamatan Dewantara, Aceh Utara, kasus pembantaian Tgk. Bantaqiah beserta sejumlah santrinya, peristiwa pembantaian terhadap

\footnotetext{
${ }^{1}$ Syamsu Rizal Panggabean, Manajemen Konflik Berbasis Sekolab: Dari Sekolab Sukma Bangsa Untuk Indonesia, Cetakan 1 (Ciputat, Tangeran Selatan, Indonesia: PT Pustaka Alvabet, 2015), vii.

2 Yanuarti Dalam Miftahul Jannah, 'Trauma \& Tazkiyatun Nufus (pada Santri Korban Konflik Di Markaz Al-Aziziyah Lueng Bata Banda Aceh)', Gender Equality: International Journal of Child and Gender Studies 2, no. 2 (17 May 2017): 69-80, https://doi.org/10.22646/jcgs.v2i2.1467.
} 
karyawan PT. Bumi Flora dengan alasan melakukan pengejaran terhadap anggota $\mathrm{GAM}^{3}$.

Gagalnya perjanjian damai yang ditandatangani di Jenewa, Swiss, pada 9 Desember 2002, yang disponsori oleh Henry Dunant Centre, telah mengakhiri masa jeda kemanusiaan, yang berlanjut dengan penetapan Darurat Militer Aceh, pada 19 Mei 2003. Jakarta mengirimkan ribuan personil TNI/Polri ke Aceh, dengan alasan untuk menumpas GAM. Satu tahun pelaksanaan darurat militer, TNI mengklaim telah menewaskan 2.439 anggota GAM, menagkap 2.003 anggota GAM, dan 1.559 orang menyerah. Dari pihak TNI diakui 147 orang tewas dan 422 luka-luka. Selain itu, Dinas Penerangan Umum TNI juga mengakui, pelaksanan Darurat Militer juga telah menewaskan sekitar 662 warga sipil, 140 orang mengalami luka berat, dan 227 orang luka ringan. Saat perang belum lagi berakhir, tsunami menerjang Aceh pada 26 Desember 2004. Akibat peristiwa ini sekitar 129.775 orang tewas, 36.786 orang hilang, dan 174.000 orang hidup di tenda-tenda pengungsian, akibat kehilangan tempat tinggal Marzuki dan Warsidi, Bencana tsunami ini menjadi pondasi bagi semua pihak yang berkonflik di Aceh untuk berdamai. Akhirnya pada 15 Agustus 2005 ditandatangani nota kesepahaman antara Pemerintah RI dengan GAM (MoU Helsinki) yang kemudiana melahirkan perdamaian di Bumi Aceh hingga saat ini ${ }^{4}$.

Meskipun perdamaian telah di rajut sejak ditandantanginya MoU, namun konflik di Aceh masih menyisakan dampak bagi kehidupan sosial masyarakat Aceh. Konflik yang terjadi telah melahirkan kerusakan infrastruktur penting bagi penopang kehidupan sosial Aceh pasca konflik. Ekonomi masyarakat berubah, dinamika sosial politik berubah dan hubungan sosial masyarakat juga ikut berubah. Konflik juga masih menyisakan trauma psikologis yang dalam

3 Wahyudi Djafar, 'Menyelesaikan Masa Lalu, Memulihkan Aceh Sepenuhnya', Juris: Lembaga Kajian Keilmuan Fakultas Hukum UI, 2011.

${ }^{4}$ Nashrun Marzuki; Adi Warsidi; Fakta bicara: mengungkeap pelanggaran HAM di Aceh 1989-2005 (Koalisi NGO HAM Aceh, 2011), //perpustakaan.elsam.or.id/index.php?p=show_detail\&id=13260. 
bagi masyarakat Aceh terutama bagi perempuan dan anak-anak. Miftahul Jannah ${ }^{5}$ dalam penelitiannya terhadap santri yang berasal dari berbagai daerah di Aceh terutama anak-anak yatim yang orang tuanya menjadi korban konflik menyatakan bahwa konflik di Aceh masih menyisakan trauma pada anak-anak korban konflik yang saat ini sudah berusia di dewasa. Ada yang menyimpan dendam dan ada yang tidak, namun secara tidak langsung pengaruh konflik nampak dari tingkah laku dan cara berpikir mereka.

Konflik secara langsung juga berdampak pada dinamika pendidikan di Aceh, infrasturktur pendidikan hancur, jam sekolah di batasi, bayang-bayang konflik dan kekerasan selalu menghantui peserta didik pada masa konflik sehingga pendidikan yang diterima tidak memadai. Terkait dampak konflik terhadap pendidikan, Miss Komareeyah Sulong ${ }^{6}$ dalam penelitiannya di Thailand mencatat bahwa konflik telah mengakibatkan dikuranginya jam belajar, prestasi belajar siswa menurun, kinerja guru menurun, perubahan sistem pendidikan sekolah selalu berubah sesuai dengan kebijakan pemerintah dalam rangka resolusi konflik, sekolah harus libur secara mendadak ketika terjadi konflik. Sedangkan resolusi konflik dapat meningkatkan kualitas kinerja guru dalam proses pembelajaran di sekolah agama Islam swasta, membangunkan semangat guru dalam proses pembelajaran di sekolah, membangunkan semangat siswa dalam proses pembelajaran di sekolah, menciptakan suasana yang aman, damai dan sejahtera di sekolah.

Berdasarkan pemaparan di atas, tulisan ini bermaksud mengkaji tentang bagaimana pengaruh konflik terhadap pengembangan pendidikan di Aceh saat ini. Aceh sebagai daerah yang terpapar konflik berkepanjangan sebagaimana di ungkapkan pada poin pertama tulisan ini tentu memiliki dinamika yang berbeda dengan daerah lain yang tidak

\footnotetext{
${ }^{5}$ Jannah, 'Trauma \& Tazkiyatun Nufus (pada Santri Korban Konflik Di Markaz Al-Aziziyah Lueng Bata Banda Aceh)'.

6 MISS KOMAREEYAH SULONG, 'Dampak Resolusi Konflik Terhadap Sistem Pendidikan Agama Islam Di Sekolah Songserm Islam Seksa Patani, Thailand Selatan' (skripsi, UNIVERSITAS ISLAM NEGERI SUNAN KALIJAGA, 2014), http://digilib.uin-suka.ac.id/14786/10/small.jpg.
} 
berkonflik, tertutama dalam pengembangan pendidikannya. Kajian ini dibatasi pada aspek konflik dan dampaknya pada pengembangan dunia pendidikan di Aceh saat ini. Tulisan ini disusun dengan menggunakan pendekatan studi literatur, dimana data dihimpun dari sumber-sumber skunder yang berupa dokumen-dokumen terkait kinerja pembangunan pendidikan saat ini, serta hasil-hasil kajian para pakar/penelitian terkait konflik dan pembangunan dunia pendidikan.

\section{Pembahasan dan Analisis}

Konflik merupakan suatu kenyataan hidup yang tidak terhindarkan dan sering bersifat kreatif. Konflik juga merupakan realitas yang tersebar dimana-mana dan pasti ada dalam setiap struktur sosial masyarakat. Konflik terjadi ketika tujuan masyarakat tidak berjalan dengan baik atau tidak sejalan. Berbagai perbedaan pendapat dan konflik sering menghasilkan sistuasi yang lebih baik bagi sebagian besar masyarakat atau semua pihak yang terlibat ${ }^{7}$. Secara sosiologis, konflik pada dasarnya menimbulkan akibat-akibat atau resiko-resiko tertentu yang bersifat destruktif maupun konstruktif. Selain dampak negatif, konflik juga berdampak positif bagi dinamika kehidupan sosial masyarakat. Lewis Coser dalam bukunya The Function of Conflict menyatakan bahwa konflik memiliki fungsi positif ketika dikelola dan di ekspresikan sewajarnya. Setidaknya ada empat fungsi konflik menurut Lewis A. Coser $^{8}$ yaitu:

1) Konflik dapat membantu mengeratkan ikatan kelompok yang secara longgar. Masyarakat yang mengalami disintegrasi atau berkonflik dengan masyarakat lain, dapat memperbaiki kepaduan integrasi.

2) Konflik dapat membantu menciptakan kohesi melalui aliansi dengan kelompok lain.

3) Konflik dapat membantu mengaktifkan peran individu yang semula terisolasi.

${ }^{7}$ Simon Fisher et al., Mengelola konflik: ketrampilan \& strategi untuk bertindak (Jakarta [etc.: Zed Books ; British Council ; Responding to Conflict (RTC), 2001), 4.

${ }^{8}$ George Ritzer, Sociological Theory, 8. ed (New York: McGraw-Hill, 2011), 456-58. 
4) Konflik juga memungkinkan pihak yang bertikai menemukan ide yang lebih baik mengenai kekuatan relatif mereka dan meningkatkan kemungkinan untuk saling mendekati atau saling berdamai

Dalam kaitannya dengan dampak atau pengaruh yang dihasilkan oleh suatu konflik, Sudjana ${ }^{9}$ yang dikutip Muliati menyatakan bahwa:

1) Konflik dapat menghambat upaya bersama untuk memenuhi kebutuhan kelompok/ organisasi dan perorangan.

2) Di pihak lain, konflik dapat menguntungkan kegiatan kelompok apabila konflik tersebut dapat merangsang timbulnya gagasan-gagasan baru untuk meningkatkan efesiensi dan efektivitas kegiatan kelompok, mengarahkan kreativitas kelompok dalam memecahkan masalah yang dihadapi. Konflik ini dapat dimanfaatkan agar kelompok lebih tanggap terhadap kebutuhan anggota.

Selain itu, konflik sebagai suatu fenomena sosial dapat dipandang sebagai suatu dinamika yang mendorong lahirnya perubahan sosial dengan asumsi bahwa suatu perubahan sosial tidak hanya terjadi melalui proses penyesuaian nilai-nilai yang membawa perubahan, tetapi terjadi akibat adanya konflik yang menghasilkan kompromi-kompromi yang berbeda dengan kondisi semula ${ }^{10}$. Kaitannya dengan kasus konflik di Aceh berdasarkan persepektif konflik yang dipaparkan di atas dapat dikatakan bahwa konflik Aceh selama tiga dekade terakhir secara sosiologis tidak hanya berdampak destruktif tetapi juga pasti memiliki dampak-dampak yang kosntruktif dalam beberapa bidang pasca lahirnya perdamaian terutama dalam bidang pendidikan.

9 Indah Muliati, 'Manajemen Konflik Dalam Pendidikan Menurut Perspektif Islam', TINGKAP 12, no. 1 (1 April 2016): 39-52.

${ }^{10}$ Bernard Raho, Teori sosiologi modern, 2007, 54. 


\section{Pendidikan di Aceh dalam Lintas Sejarah}

Sejarah Aceh mencatat bahwa pendidikan telah berkembang sangat pesat di Aceh ketika sejak masa Sultan Iskandar Muda (16071636). Abdul Majid dan Sofyan Djalil dalam Orasi Ilmiahnya yang disampaikan pada Rapat Terbuka dalam rangka Dies Natalis ke-45 Unsyiah pada 2 September 2006 menyebutkan bahwa penjelajah Perancis yang bernama Beaulieu melawat Aceh pada abad ke-17 menyatakan bahwa pada kurun waktu tersebut Aceh sudah tidak mengenal masyarakat buta huruf. Pada masa itu di Aceh telah berdiri dengan megahnya sebuah institus pendidikan tinggi setingkat Universitas yang diberi nama Jami'ah Baiturrahman yang berlokasi di Mesjid Baiturrahman, mesjid kebanggaan rakyat Aceh. Sistem pendidikan di Jami'ah ini sudah diintegrasikan ilmu pendidikan umum dan agama untuk diajarkan kepada para mahasiswanya. Institusi pendidikan di Aceh yang sangat berwibawa ketika itu telah menjadi sentra pengembangan ilmu pengetahuan di Aceh hingga kawasan regional manca negara. Tenaga pengajar dan guru besar Jami'ah Baiturrahman ini mencakup ulama-ulama besar yang bukan saja berketurunan Aceh, seperti Syeikh Nuruddin Ar-Raniry, Syeikh Syamsuddin As-Sumatrani dan juga Syeikh Hamzah Al Fansury ${ }^{11}$

Selanjutnya, pada tahun 1939 di bawah kepemimpinan Daud Beureueh, PUSA berdiri sebagai organisasi ulama yang juga bergerak dalam bidang pendidikan. Mereka membangun dayab-dayah (pesantren) bagi kelancaran pendidikan di Aceh dan kemudian dayah menjadi basis sosial yang cukup ampuh untuk membangun ideologi dan pergerakan, terutama pada masa perlawanan terhadap Belanda. Sistem pendidikan tersebut terus bertahan hingga Aceh menjadi bagian dalam negara Indonesia $^{12}$. Pada tanggal 24 April 1962 di Kopelma Darussalam, Banda Aceh berdiri Universitas Syiah Kuala (Unsyiah) yang

${ }^{11}$ M. Shabri Abd Majid, 'Analisis Tingkat Pendidikan Dan Kemiskinan Di Aceh', Jurnal Pencerahan 8, no. 1 (15 March 2014): 20, https://doi.org/10.13170/jp.8.1.2040.

12 Siti Ikramatoun, 'Institusi kepemimpinan adat Aceh: peran wali Nanggroe dan respon masyarakat $=$ Aceh traditional leadership institutions: the role of Wali Nanggroe and public response / Siti Ikramatoun' (Universitas Indonesia, 2014), 45, http:/ /ib.ui.ac.id/detail?id=20404038\&lokasi=lokal. 
dikukuhkan dengan Keputusan Presiden Republik Indonesia, nomor 161 tahun 1962. Lalu pada tanggal 05 Oktober 1963 IAIN Ar-raniry diresmikan. Di Aceh Barat, pada tahun 1983 para ulama dan pemuka masyarakat Aceh Barat bekerjasama dengan pemerintah Kabupaten Aceh Barat merintis berdirinya suatu yayasan pendidikan yang saat ini dikenal dengan Universitas Teuku Umar (UTU). Universitas Muhammadiyah Aceh (UNMUHA) diresmikan pada tanggal 11 Maret 1987. Universitas Muhammadiyah Aceh merupakan pengembangan dari Sekolah Tinggi Ilmu Hukum (STIH) Muhammadiyah Banda Aceh yang didirikan pada tahun 1969. Dan di Aceh Utara pada tahun 1970 berdiri sebuah perguruan tinggi yang kemudian dikenal sebagai Universitas Malikussaleh.

Dari gambaran diatas terlihat jelas bahwa dalam rentang sejarah perjalanan Aceh sebagai sebuah daerah yang selalu berkonflik, aspek pendidikan juga terus berkembang dan tumbuh di wilayah ini. Pendidikan di Aceh dalam lintas sejarah jelas menunjukkan bahwa aspek pendidikan bagi masyarakat Aceh merupakan sesuatu yang penting bahkan menjadi salah satu basis sosial perkembangan masyarakat Aceh saat ini.

\section{Pengaruh Konflik Terhadap Pembangunan Pendidikan Di Aceh}

a) Pegaruh Negatif

Di Aceh, infrastruktur pendidikan sengaja dijadikan target selama konflik. Diperkirakan 49 persen sekolah menengah atas, 47 persen sekolah menengah pertama, 54 persen sekolah dasar, dan madrasah tradisional (sekolah Islam), dan 74 persen taman kanakkanak rusak selama konflik di Aceh. Selama konflik. Bank Dunia mencatat sektor pendidikan adalah yang paling besar terkena dampak konflik, yakni sebanyak 900 sekolah hancur pada masamasa konflik terparah mulai tahun 1999 dan seterusnya. Selain itu, sekolah-sekolah seringkali ditutup sementara terutama pada saat kekerasan meningkat. Selama enam bulan setelah kegagalan Perjanjian Penghentian Permusuhan pada bulan Mei 2003, 880 sekolah harus ditutup dan beberapa universitas juga diserang. 
Bahkan pada priode ini diperkirakan lebih dari 180.000 orang meninggalkan Aceh, dan ratusan mahasiswa Universitas Syiah Kuala melanjutkan pendidikan mereka di luar Aceh ${ }^{13}$

Selain hancurnya infrastruktur pendidikan, pengaruh yang cukup signifikan dari konflik yang terjadi di Aceh adalah lahirnya sumber daya manusia Aceh yang rendah. Hal ini terjadi karena pada masa konflik banyak warga aceh yang menjadi korban dan melakukan migrasi keluar aceh. Dinas Pendidikan Aceh melaporkan nilai ujian akhir pelajar SD hingga SMA menurun drastis dan banyak pelajar yang akhirnya menjadi bagian pelaku konflik secara terpaksa maupun dipaksa. Masa belajar mereka dirampas untuk menjadi child soldier. Peristiwa konflik juga membuat sistem pendidikan terganggu, guru memilih untuk tidak hadir kesekolah demi keselamatan, bahkan banyak guru yang memilih hijrah keluar Aceh sehingga warga Aceh tidak memperoleh pendidikan yang layak. Disamping itu, pelayanan pendidikan menjadi sangat buruk, gedung sekolah yang tersisa menjadi tidak terurus, muncul pajak-pajak ilegal yang merugikan dunia pendidikan dan lembaga pemerintah menjadi tidak berdaya. Akibatnya perkembangan Aceh menuju pembangunan manusia dari jalur pendidikan mengalami penurunan dibandingkan dengan provinsi-provinsi lainnya. Banyak pula keluarga kehilangan pekerjaan dan mata pencaharian sehingga tidak mampu menyekolahkan anaknya. Kondisi-kondisi tersebut merupakan dampak nyata dari peristiwa konflik yang terjadi, dan tentunya selain dampak fisik, dampak psikologis yang berupa trauma juga dialami oleh pelajar Aceh terutama anak-anak yang menjadi korban kekerasan.

13 The World Bank, Diagnosis Pertumbuhan Aceh : Mengidentifikasi HambatanHambatan Utama Pertumbuhan Ekonomi Pasca Konflik Dan Pasca Bencana' (The World Bank, July 2009), 43 , http://documents.worldbank.org/curated/en/194571468260138382/Diagnosispertumbuhan-Aceh-mengidentifikasi-hambatan-hambatan-utama-pertumbuhanekonomi-pasca-konflik-dan-pasca-bencana. 
b) Pengaruh Positif

Secara teoritis, konflik memang dapat melahirkan dampakdampak negatif sebagaimana disebutkan diatas, namun konflik tentunya juga akan melahirkan kondisi damai jika konflik yang terjadi dapat diselesaikan dengan baik. Kondisi damai pasca konflik jika dikelola dengan baik akan melahirkan perubahan yang baik bagi masyarakat. Karena pada dasarnya konflik merupakan salah satu penggerak lahirnya suatu perubahan sosial. Demikian pula yang terjadi di Aceh, peristiwa konflik berkepanjangan yang telah menghancurkan sendi-sendi kehidupan masyarakat, pasca konflik kembali dibenahi dan di dorong untuk kembali mengejar ketertinggalannya dari daerah-daerah lain. Dunia pendidikan yang terdampak konflik mulai dibenahi dan mulai mencari jati dirinya kembali.

Kondisi Aceh pasca konflik dalam bidang pendidikan menunjukkan kondisi angka yang cukup menggembirakan, telah terjadi akselerasi yang cukup tinggi pasca konflik. Hal ini dapat dilihat dari tingkat partisipasi pendidikan masyarakat Aceh yang lebih tinggi dibandingkan dengan rata-rata partisipasi daerahdaerah di Indonesia. Salah satu penyebab tingginya tingkat partisipasi ini adalah terciptanya kondisi damai di Aceh yang membuat masyarakat menyadari ketertinggalannya dari daerah lain sehingga berusaha mengejar ketertinggalan itu secepat mungkin. Konflik telah menjadi dasar akselerasi pembangunan pendidikan di Aceh. Dengan kata lain, konflik yang terjadi berkepanjangan telah menjadi motor penggerak pembangunan pendidikan di Aceh sehingga terjadi perubahan yang signifikan.

Kondisi pendidikan Aceh yang meningkat pasca konflik sejalan dengan hasil penelitian ILO pada tahun 2010, yakni 4 tahun pasca konflik yang menunjukkan bahwa sepertiga angkatan kerja di Aceh sekurang-kurangnya mempunyai tingkat pendidikan sekolah menengah dan 9,9\% mempunyai pendidikan diploma atau di atasnya, sementara rata-rata nasional masing-masing hanya 
sebesar 29,4\% dan 7,1\%. Pekerja perempuan di Aceh mempunyai tingkat capaian pendidikan yang secara signifikan lebih tinggi, 15\% diantaranya pendidikan diploma atau diatasnya, sementara di sisi lain hanya 7,3\% pekerja laki-laki yang mencapai tingkat pendidikan yang sama. (ILO, Agustus 2010). Hasil penelitian lain juga menunjukkan bahwa dibandingkan dengan tingkat pendidikan penduduk di 34 Provinsi lainnya di Indonesia, indikator tingkat pendidikan penduduk Aceh seperti Angka Partisipasi Kasar (APK), Angka Melek Huruf (AMH), Angka Rata-rata Lama Sekolah (ARLS), dan Angka partisipasi Murni (APM) sudah jauh lebih baik dan bahkan berada di atas level nasional. Indikator tingkat pendidikan mayoritas kabupaten/kota di Aceh sudah cukup baik, hanya saja mutunya masih sangat memprihatinkan. Mutu pendidikan Aceh berada pada rangking 25 dari 34 Provinsi di Indonesia. Hal ini terjadi karena pembangunan sektor pendidikan belum merata antar kabupaten/kota di Aceh ${ }^{14}$

Kondisi pembangunan pendidikan sebagaimana digambarkan diatas menunjukkan bahwa peristiwa konflik yang berkepanjangan memberikan efek yang cukup baik dibidang pendidikan pasca konflik. Penduduk Aceh yang sebelumnya sulit mengenyam pendidikan karena alasan keamanan, pasca konflik bertumbuh meningkat partisipasi masyarakat terhadap pendidikan. Tingginya tingkat partisipasi tersebut tentunya tidak terjadi begitu saja tetapi terkait erat dengan kondisi konflik dimasa lalu. Masayarakat Aceh kini berusaha mengejar ketertinggalan mereka dalam bidang pendidikan, yakni dengan memunculkan partisipasi yang tinggi terhadap pendidikan. Hal ini berarti bahwa konflik Aceh telah memberikan efek kosntruktif bagi pembangunan pendidikan masyarakatnya meskipun dalam aspek mutu pendidikan masih banyak hal yang harus di benahi.

${ }^{14}$ Majid, 'Analisis Tingkat Pendidikan Dan Kemiskinan Di Aceh'. 
Secara garis besar ada beberapa kondisi yang menyebabkan akselerasi bidang pendidikan di Aceh yang dipengaruhi oleh peristiwa konflik, yaitu:

1) Pengesahan Undang-Undang No. 11 Tahun 2006 tentang Pemerintah Aceh (UUPA) yang merupakan salah satu buah perdamaian karena merupakan bagian dari perjanjian damai (MoU Helsinki), dan pengesahan UUPA ini merupakan tonggak bagi reformasi pendidikan di Aceh.

2) Kekhususan dan keistimewaan provinsi Aceh dimana Pemerintah Aceh memiliki kewenangan untuk menyelenggarakan pendidikan sesuai dengan karakteristik, potensi, dan kebutuhan masyarakat Aceh, yaitu pendidikan yang Islami sebagaimana yang telah ditetapkan dalam Qanun No. 5 Tahun 2008 tentang Penyelenggaraan Pendidikan.

3) Adanya Majelis Pendidikan Daerah (MPD) yang merupakan sebuah badan berbasis masyarakat, berfungsi memberikan pendapat, saran dan pertimbangan kepada pemerintah daerah mengenai kebijakan dan pelaksanaan pendidikan di Aceh. Kelembagaan MPD ini pada dasarnya sudah ada sejak tahun 1990 melalui Surat Keputusan Gubernur No. 420/435/1990 tentang pembentukan Majelis Pendidikan Daerah (MPD), namun secara praktis lembaga ini baru bejalan efektif dan akseleratif membangun pendidikan Aceh pasca konflik yakni pada tahun 2006 terbit Qanun Nomor 3 tentang Susunan Organisasi dan Tata Kerja Majelis Pendidikan Daerah (MPD) Provinsi Aceh.

4) Janji Pemerintah Aceh untuk memberikan pendidikan gratis bagi siswa yang berusia 7 hingga 18 tahun dan diwujudkan engan disahkannya Qanun No. 5 Tahun 2008 tentang Penyelenggaraan Pendidikan

5) Program beasiswa dari pemerintah Aceh,yang dikhususkan kepada rakyat Aceh yang terkenal dengan dikelola oleh Lembaga Peningkatan Sumber Daya Manusia (LPSDM). 


\section{Pendidikan di Aceh Saat ini}

Sukses tidaknya pembangunan pendidikan suatu daerah secara umum dapat diketahui dari beberapa indikator seperti jumlah fasilitas pendidikan, angka partisipasi sekolah, tingkat pendidikan yang ditamatkan, dan angka melek huruf. Pada tahun 2010 rangking pendidikan Aceh berada di nomor 25, dari 34 Provinsi yang ada di Indonesia $^{15}$. Data dari Kementerian Pendidikan dan Kebudayaan, juga menunjukkan bahwa lulusan peserta ujian nasional (UN) tahun 2014 untuk tingkat Sekolah Menengah Atas (SMA) dari 34 provinsi di Indonesia, Provinsi Aceh menempati jumlah tertinggi siswa yang tak lulus, yaitu sebanyak 784 (1,38\%) siswa dari 56.981 siswa.

Meskipun demikian, kondisi pendidikan Aceh secara keseluruhan menunjukkan peningkatan. Data BPS menunjukkan bahwa rata-rata angka partisipasi sekolah (APS) Provinsi Aceh tahun 2013 sebesar 99,66 persen untuk usia 7-12 tahun dan 95,2 persen untuk usia 13-15 tahun. Kabupaten di Provinsi Aceh dengan APS terendah meliputi Kabupaten Simeuleu dan Kota Langsa. Untuk tingkat SMA 80,89 persen penduduk usia 16 - 18 tahun telah menikmati pendidikan. Kemudian pada tahun 2015 angka harapan lama sekolah (HLS) masyarakat Aceh adalah 13,39 tahun, lebih baik HLS nasional sebesar 12,39 tahun. Hal ini menunjukkan bahwa anak-anak usia 7 tahun memiliki peluang untuk menamatkan pendidikan mereka hingga lulus SMA atau D1. Kenaikan HLS ini merupakan indikasi bahwa telah terjadi perbaikan kondisi pendidikan di Aceh ${ }^{16}$

Semangat generasi awal pembangunan pendidikan Aceh tampak nyata pada tingginya akses pendidikan Aceh saat ini. Aceh adalah provinsi yang akses pendidikannya di atas rata-rata Nasional. Angka Partisipasi Kasar (APK) SD/MI (usia 7-12 tahun) di Aceh sudah lebih 100 persen sejak 2009, demikian juga APK SMP/MTs

\footnotetext{
15 Majid, 16.

16 'Indikator Kesejahteraan Rakyat Provinsi Aceh 2016' (Badan Pusat Statistik Provinsi Aceh, 2017), https://aceh.bps.go.id/publication/2017/11/22/223351a67c8d66713ee5f6b9/indika tor-kesejahteraan-rakyat-provinsi-aceh-2016.html.
} 
(usia 13-15 tahun) dan SMA/MA (16-18) dengan trend yang sama. Menurut Laporan Perkembangan Pendidikan Aceh (LPPA) 2011, angka partisipasi kasar (APK) Perguruan Tinggi di Aceh untuk usia 1923 tahun sebesar 29,76 persen, berada pada posisi ke-6 setelah DKI Jakarta (155,36 persen), Yogyakarta (65,24 persen), Sulawesi Selatan (34,46 persen), Gorontalo (33,3 persen), dan Sumatera Barat (29,98 persen). Sedangkan Target Nasional pada tahun 2014 adalah sebesar 30 persen. Artinya, dari setiap 100 jiwa penduduk berusia 19-23 tahun di Aceh, sekitar 30 di antaranya tercatat sebagai mahasiswa. Angka melek huruf (literacy rate) penduduk dewasa di Aceh saat ini juga sangat tinggi, yakni mencapai 95,8 persen pada 2011, sementara rata-rata Nasional berada pada angka 92,8 persen (Mahdi Serambi, 6/9/2016).

Angka-angka tersebut diatas secara kuantitatif dapat dipahamai sebagai suatu keberhasilan pembangunan pendidikan di Aceh. Karena pada masa konflik tingkat partisipasi masyarakat terhadap pendidikan sangat rendah, tetapi pasca konflik partisipasi bertumbuh dengan cepat, bahkan melebihi daerah lain yang tidak terdampak konflik. Dapat dikatakan bahwa konflik telah menyadarkan masyarakat Aceh bahwa mereka telah tertinggal begitu jauh dari daerah lain sehingga memerlukan akselerasi untuk mengejar ketertinggalan itu.

\section{Kesimpulan}

Sejak masa Belanda sampai Orde Baru hingga reformasi, Aceh selalu bergejolak dengan konflik, ribuan nyawa melayang, ratusan infrastruktur hancur, kehidupan sosial kacau dan pendidikan masyarakat terganggu. Belum selesai konflik, Tsunami kembali memporak-porandakan Aceh. Konflik yang bekepanjangan telah melahirkan sumber daya manusia aceh yang rendah. Akibat konflik pula ratusan hingga ribuan penduduk Aceh harus keluar dari daerahnya, perekonomian lumpuh dan pendidikan tak terurus. Namun hikmah besar setelah kesepakatan damai berhasil dicapai yakni lahirnya generasi Aceh baru yang berusaha mengejar ketertinggalan dari derah lainnya. 
Konflik memang tidak selalu negatif, tetapi juga fungsional terutama sebagai penggerak lahirnya suatu perubahan sosial. Pasca konflik partisipasi pendidikan masyarakat bertumbuh dengan cepat dan melebihi daerah lain yang tidak terdampak konflik. Hal ini berarti konflik yang berkepanjangan memberikan andil dalam akselerasi pembangunan pendidikan bagi masyarakat Aceh saat ini. Dalam bahasa lain, konflik telah menyadarkan masyarakat Aceh bahwa mereka telah tertinggal begitu jauh dari daerah lain sehingga dibutuhkan akselerasi untuk mengejar ketertinggalan itu.

Secara garis besar terdapat beberapa kondisi yang menjadi alasan akselerasi pembangunan pendidikan di Aceh pasca konflik, diantaranya adalah rendahnya sumber daya manusia aceh akibat konflik, lahirnya perdamaian yang berdampak pada disahkannya UUPA, adanya Majelis Pendidikan Aceh, besarnya beasiswa yang diberikan kepada rakyat aceh, kehususan Aceh seebagai daerah otonomi khusus dengan bantuan dana yang besar serta kebebasan mengelola sektor pendidikan sesuai dengan kearifan lokal serta beberapa kondisi lainnya sepertia peristiwa gempa bumi dan tsunami yang kemudian mendatangkan banyak bantuan kepada Aceh, termasuk ke sektor pendidikan.

Kesuksesan pembangunan pendidikan di Aceh saat ini memang telah melampaui angka rata-rata nasional. Namun keberhasilan tersebut tentunya masih menyisakan banyak masalah, terutama pada aspek mutu pendidikannya sehingga masih dibutuhkan beberapa intervensi dan program strategis untuk mendorong mutu pendidikan agar semakin baik. Dengan kata lain, fokus pembangunan pendidikan Aceh saat ini sudah harus bergerser ke arah pembangunan kualitas pendidikan bukan lagi pada aspek aksesibilitas dan partisipasi pendidikan karena hal itu sudah terlampaui. Yang perlu dilakukan oleh pemerintah Aceh adalah mendorong lahirnya mutu pendidikan yang tinggi dan berdaya saing sebagaimana daerah lainnya, yakni dengan mengarahkan program pembangunan pendidikan kearah pembangunan kualitas pendidik dan peserta didik agar mutu pendidikan Aceh meningkat. 


\section{Referensi}

Bank, The World. 'Diagnosis Pertumbuhan Aceh: Mengidentifikasi Hambatan-Hambatan Utama Pertumbuhan Ekonomi Pasca Konflik Dan Pasca Bencana'. The World Bank, 1 July 2009. http://documents.worldbank.org/curated/en/1945714682601 38382/Diagnosis-pertumbuhan-Aceh-mengidentifikasihambatan-hambatan-utama-pertumbuhan-ekonomi-pascakonflik-dan-pasca-bencana.

Djafar, Wahyudi. 'Menyelesaikan Masa Lalu, Memulihkan Aceh Sepenuhnya'. Juris: Lembaga Kajian Keilmuan Fakultas Hukum UI, 2011.

Fisher, Simon, S.N Kartikasari, Responding to Conflict (RTC) (Birmingham), and British Council (Indonesia). Mengelola konflik: ketrampilan \& strategi untuk bertindak. Jakarta [etc.: Zed Books ; British Council ; Responding to Conflict (RTC), 2001.

Ikramatoun, Siti. 'Institusi kepemimpinan adat Aceh: peran wali Nanggroe dan respon masyarakat $=$ Aceh traditional leadership institutions: the role of Wali Nanggroe and public response / Siti Ikramatoun'. Universitas Indonesia, 2014. http:/ /lib.ui.ac.id/detail?id=20404038\&lokasi=lokal.

'Indikator Kesejahteraan Rakyat Provinsi Aceh 2016'. Badan Pusat Statistik Provinsi Aceh, 2017. https://aceh.bps.go.id/publication/2017/11/22/223351a67c8 d66713ee5f6b9/indikator-kesejahteraan-rakyat-provinsi-aceh2016.html.

Jannah, Miftahul. 'Trauma \& Tazkiyatun Nufus (pada Santri Korban Konflik Di Markaz Al-Aziziyah Lueng Bata Banda Aceh)'. Gender Equality: International Journal of Child and Gender Studies 2, no. 2 (17 May 2017): 69-80. https://doi.org/10.22646/jcgs.v2i2.1467.

Majid, M. Shabri Abd. 'Analisis Tingkat Pendidikan Dan Kemiskinan Di Aceh'. Jurnal Pencerahan 8, no. 1 (15 March 2014). https://doi.org/10.13170/jp.8.1.2040. 
MISS KOMAREEYAH SULONG. 'Dampak Resolusi Konflik Terhadap Sistem Pendidikan Agama Islam Di Sekolah Songserm Islam Seksa Patani, Thailand Selatan'. Skripsi, UNIVERSITAS ISLAM NEGERI SUNAN KALIJAGA, 2014. http://digilib.uin-suka.ac.id/14786/10/small.jpg.

Muliati, Indah. 'Manajemen Konflik Dalam Pendidikan Menurut Perspektif Islam'. TINGKAP 12, no. 1 (1 April 2016): 39-5252.

Mahdi, Saiful.. Pendidikan Aceh; Akses, Mutu, atau Relevansi?. Serambi Indonesia. $2016 \quad$ Di akses dari bttp:/ / aceh.tribunnews.com/2016/09/06/pendidikan-aceb-akses-mutuatau-relevansi. Pada tanggal 22 Juli 2019

Mahjuddin, Akhiruddi. Dampak Konflik Terhadap Perkembangan Ekonomi Dan Tingkat Kesejabteraan Rakyat (Studi Kasus Aceh), Tesis: Fakultas Ekonomi Program Magister Perencanaan Dan Kebijakan Publik. 2012

Nashrun Marzuki dan Adi Warsidi (ed). 2011. Fakta Bicara: Mengungkap Pelanggaran HAM di Aceh 1989 - 2005. Banda Aceh: Koalisi NGO HAM Aceh

Panggabean, Syamsu Rizal. Manajemen Konflik Berbasis Sekolab: Dari Sekolah Sukma Bangsa Untuk Indonesia. Cetakan 1. Ciputat, Tangeran Selatan, Indonesia: PT Pustaka Alvabet, 2015.

Raho, Bernard. Teori sosiologi modern, 2007.

Ritzer, George. Sociological Theory. 8. ed. New York: McGraw-Hill, 2011. 